\title{
RISK FACTORS FOR MICRO AND MACROVASCULAR DISEASE IN BLACK AND WHITE PATIENTS WITH TYPE 2 DIABETES MELLITUS
}

Caroline Kaercher Kramer ${ }^{1}$, Cristiane Bauermann Leitão², Lana Catani Pinto ${ }^{3}$, Patricia Bolson ${ }^{4}$, Juliana Boza4, Sandra Pinho Silveiro 5 , Jorge Luiz Gross ${ }^{6}$, Luis Henrique Canani*7

Trabalho realizado no Serviço de Endocrinologia do Hospital de Clínicas de Porto Alegre, RS, Brasil

\author{
*Correspondence \\ Serviço de Endocrinologia do \\ Hospital de Clínicas de Porto \\ Alegre \\ Rua Ramiro Barcelos \\ 2350, Prédio $12,4^{\circ}$ andar, \\ 90035-003, Porto Alegre, \\ RS, Brasil. \\ luiscanani@yahoo.com.br \\ Phone: + 555121018127 \\ Fax: + 555121018777
}

\begin{abstract}
SUMMARY
Risk factors for micro and macrovascular disease in black and white patients with type 2 Diabetes mellitus

BACKGRound. The prevalence of chronic complications in type 2 diabetes mellitus (DM) is higher in black patients. The reason for this finding is still unknown. The objective of this study was to analyze the micro and macrovascular risk factor profile of type 2 DM patients without advanced diabetic nephropathy according to ethnicity.

Methods. A cross-sectional multicentric regional study was conducted evaluating 780 patients. All patients were submitted to clinical and laboratory evaluation. Ethnicity was self-reported as white (n $=585)$ or black $(n=195)$.

Results. Black patients had lower triglycerides [1 15 (35-892) vs. 152 (34-1236) mg/dl; $P<0.001]$ and higher HDL-cholesterol levels than whites $(48.3 \pm 13.5$ vs. $44.8 \pm 12.1 \mathrm{mg} / \mathrm{dl} ; \mathrm{P}=0.002)$. White and black patients did not differ regarding fasting plasma glucose, A1c test, total and LDL cholesterol, blood pressure levels, insulin and HOMA-IR. There were no differences between groups regarding medication in use (statin: 18.5 vs. $19.3 \%, P=1.000$; fibrates: 1.5 vs. $0.7 \%, P=0.680$; angiotensin converting enzyme inhibitors: 39.5 vs. $43.8 \%, P=0.375$; acetylsalicylic acid: 29.9 vs.
\end{abstract} $27.7 \%, P=0.673$ ).

Conclusions. There were no differences in the prevalence of the classic micro and macrovascular risk factors between ethnic groups. The study of non-conventional risk factors and genetic factors is essential to understand determinants of the worst outcomes presented by the African-Brazilian population.

KEY WORDS: Diabetes mellitus. Ethnicity. Chronic complications. Risk factors.

\section{INTRODUCTION}

Diabetes mellitus (DM) is associated with vascular complications that lead to a major increase in mortality and morbidity ${ }^{1}$. The rate of chronic complications of DM varies among populations $^{2}$. Ethnic origin of the individuals might be involved in this difference. The most consistent data concern advanced diabetic nephropathy (DN). Prevalence of end-stage renal failure is higher in patients of African ancestry, compared with individuals of European ancestry, either in studies performed in the United States $^{3-10}$, Europe ${ }^{11}$ or in Brazil ${ }^{12}$. Moreover, this ethnic group appears to be more affected by the proliferative form of diabetic retinopathy $(\mathrm{DR})^{12}$ and by ischemic heart disease $(\mathrm{IHD})^{3,4}$.

The traditional risk factors for onset and progression of chronic complications of DM are hyperglycemia, hypertension and dyslipidemia ${ }^{13}$. The few studies in non-Brazilian populations suggest that individuals of African ancestry present a higher prevalence of hypertension ${ }^{14,15}$, insulin resistance and metabolic syndrome ${ }^{16}$ when compared to individuals of European ancestry. These changes might explain the increase in the advanced forms of DN and DR in this ethnic group. However, there are few descriptions of these characteristics in the Brazilian population related to ethnicity.

The purpose of this study was to evaluate the risk factors for micro and macrovascular DM chronic complications in patients with type $2 \mathrm{DM}$, without advanced DN, according to ethnicity.

\section{Methods}

A cross-sectional study was performed on type 2 DM outpatients participating in a multicentric cohort, which has been followed since 2002. The medical centers involved include the

\footnotetext{
1. Médica Endocrinologista, aluna do programa de doutorado em Endocrinologia da Universidade Federal do Rio Grande do Sul - UFRGS, Porto Alegre, RS

2. Médica do Serviço de Endocrinologia do Hospital de Clínicas de Porto Alegre, Porto Alegre, RS

3. Acadêmica de Medicina do Serviço de Endocrinologia do Hospital de Clínicas de Porto Alegre, Porto Alegre, RS

4. Médicas Residentes do Hospital de Clínicas de Porto Alegre, Porto Alegre, RS

5. Professora Adjunta do Serviço de Endocrinologia do Hospital de Clínicas de Porto Alegre, Porto Alegre, RS

6. Professor Titular e Chefe do Serviço de Endocrinologia do Hospital de Clínicas de Porto Alegre, Porto Alegre, RS

7. Professor Adjunto do Serviço de Endocrinologia do Hospital de Clínicas de Porto Alegre, Porto Alegre, RS
} 
Endocrine Division of Hospital de Clínicas de Porto Alegre, the Endocrine Division of Hospital Nossa Senhora da Conceição, Hospital São Vicente de Paula in Passo Fundo and Hospital da Fundação Universitária de Rio Grande. Type 2 DM was diagnosed in the absence of previous episodes of diabetic ketoacidosis, a diagnosis of DM after the age of 30 years, without any need for insulin during the first 5 years after diagnosis.

Patients answered a standard questionnaire about age, DM duration, smoking habit and medication currently used. Ethnicity was self-defined as white, black, mulatto or others, according to the methodology adopted by the Brazilian Institute of Geography and Statistics (IBGE - Instituto Brasileiro de Geografia e Estatística) ${ }^{17}$. Initially, a total of 1276 patients were identified. Patients who classified themselves as mulatto $(n=158)$ and others $(n=62)$ were excluded from the study. One hundred and ninety-five of the 1056 remaining patients were black. These patients were paired randomly and according to age of the white patients at a proportion of 1:3 (whites: $n=585$ ). Physical examination and laboratory evaluation were performed in order to analyze risk factors for chronic complications. Weight and height were measured on an anthropometric scale without shoes and wearing light clothes. Body mass index (BMI) was calculated as weight $(\mathrm{kg}) /$ height $^{2}\left(\mathrm{~m}^{2}\right)$ ratio. Waist circumference was obtained at the mid-point between the last rib and the antero-superior iliac spine, parallel to the floor, with a nondistensible measuring tape. Blood pressure (BP) was measured twice with a 5-minute interval, in a seated position on the left upper arm, with a mercury column sphygmomanometer (phases $\mathrm{I}$ and $\mathrm{V}$ of the Korotkoff sounds). Hypertension was defined by $\mathrm{BP} \geq 140 / 90 \mathrm{~mm} \mathrm{Hg}$ (average of two measurements) and/or the use of antihypertensive drugs.

The study protocol was approved by hospital research ethics committees and informed consent was obtained from all patients.

\section{Laboratory evaluation}

The urinary albumin excretion (UAE) was measured using the immunoturbidimetry technique on $24 \mathrm{~h}$ urine samples with recorded time, or in a random sample of sterile urine. Presence of microalbuminuria (UAE $20-200 \mu \mathrm{g} / \mathrm{min}$ or $17-174 \mathrm{mg} / \mathrm{l}$ ) or macroalbuminuria (UAE $>200 \mu \mathrm{g} / \mathrm{min}$ or $>174 \mathrm{mg} / \mathrm{l}$ ) was confirmed by at least two measurements during a three to sixmonth interval ${ }^{18}$.

Metabolic parameters were analyzed in the morning, after 12 hours of fasting. Glucose levels were determined by the glucose oxidase method and creatinine by the Jaffé reaction. $A_{1 c}$ test was measured by HPLC (high performance liquid chromatography) in a Merck-Hitachi 9100 apparatus, using the column method with cation exchange and reference values of $4-6 \%$. The lipid profile was measured by an enzymatic method and LDL-cholesterol was calculated by the Friedewald equation. Serum insulin was dosed by radioimmunoassay (Elecsys R. Systems 1010 / 2010 / modular analysis E170 - ROCHE). Insulin resistance was estimated calculating the Homeostasis Model Assessment [HOMA-IR = (fasting insulin $(\mathrm{mU} / \mathrm{ml}) \times$ fasting plasma glucose $(\mathrm{mg} / \mathrm{dl}) / 18) / 22.5]^{19}$

Glomerular filtration rate (eGFR)was estimated by the equation recommended by the National Kidney Foundation (NKF) based on Modification of Diet in Renal Disease study (MDRD): $\left(\mathrm{ml} \times \mathrm{min}^{-1} \times 1.73 \mathrm{~m}^{-2}\right)=186 \times$ [serum creatinine ${ }^{-1,154} \times$ age $^{-0,203}$ $\times 0.742$ (if female) $\times 1.212$ (if African ethnicity) ${ }^{4}$. Patients with stage 4 chronic kidney disease or worse (eGFR $<30 \mathrm{ml} / \mathrm{min} / 1.73$ $\mathrm{m}^{2}$ ) were excluded to avoid clinical and laboratory alterations secondary to uremia ${ }^{20}$.

For analytical purposes, each risk factor for vascular disease was considered present according to the following criteria: waist $\geq 88 \mathrm{~cm}$ for women and $\geq 102 \mathrm{~cm}$ for men; systolic BP (SBP) $\geq 135 \mathrm{~mm} \mathrm{Hg}$, diastolic BP (DBP) $\geq 85 \mathrm{~mm} \mathrm{Hg}$; total cholesterol $>200 \mathrm{mg} / \mathrm{dl}$; LDL cholesterol > $100 \mathrm{mg} / \mathrm{dl}$; HDL cholesterol $<50$ $\mathrm{mg} / \mathrm{dl}$ for women and $<40 \mathrm{mg} / \mathrm{dl}$ for men; triglycerides $>150$ $\mathrm{mg} / \mathrm{dl}$ and; Alc $>7.0 \%$, fasting plasma glucose $\geq 110 \mathrm{mg} / \mathrm{dl}$. Since the reference values for HOMA among diabetic subjects is not well established, the upper tertile of the entire group was considered abnormal.

\section{Statistical analysis}

Data were described as mean \pm standard deviation or absolute and percentage numbers. Qualitative variables were compared using the Chi-square test. Means were compared using the Student $t$ test. Continuous variables without normal distribution were log-transformed. $P<0.05$ was considered to be significant.

\section{RESULTS}

A total of 780 patients with type 2 DM (273 males, 585 whites) were included.

No differences were found between white and black patients, respectively, in DM duration (9.6 \pm 7.7 vs. $8.8 \pm 7.3$ years, $\mathrm{P}=0.201)$, BMI $\left(29.7 \pm 5.5\right.$ vs. $29.9 \pm 5.0 \mathrm{~kg} / \mathrm{m}^{2}, \mathrm{P}=$ 0.182 ), waist circumference (women: $97.3 \pm 12.6$ vs. $98.4 \pm$ $13.1 \mathrm{~cm}, \mathrm{P}=0.482$; men: $100 \pm 11.2$ vs. $98.9 \pm 9.6 \mathrm{~cm}, \mathrm{P}$ $=0.484$ ), levels of systolic or diastolic BP (systolic: $139.9 \pm$ 22.7 vs. $139.6 \pm 22.1 \mathrm{~mm} \mathrm{Hg}, P=0.854$; diastolic: $86.2 \pm$ 12.5 vs. $86.2 \pm 12.9 \mathrm{~mm} \mathrm{Hg}, P=0.956)$ and prevalence of hypertension $(62.1 \%$ vs. $67 \%, P=0.284)$ (Table 1$)$.

Black patients presented lower levels of triglycerides [115 (35-892) vs. 152 (34-1236) $\mathrm{mg} / \mathrm{dl} ; \mathrm{P}<0.001$ ] and a higher HDL $(48.3 \pm 13.5$ vs. $44.8 \pm 12.1 \mathrm{mg} / \mathrm{dl} ; \mathrm{P}=0.002)$ than whites. Fasting glycemia (180.7 \pm 74 vs. $167.5 \pm 80.9 \mathrm{mg} /$ $\mathrm{dl}, \mathrm{P}=0.070), \mathrm{Alc}$ test $(7.2 \pm 2.2$ vs. $7.3 \pm 2.5 \%, \mathrm{P}=$ $0.840)$, total cholesterol (212.7 \pm 46.5 vs. $209.2 \pm 51.7 \mathrm{mg} /$ $\mathrm{dl}, \mathrm{P}=0.428)$ and LDL levels ( $133.2 \pm 43.8$ vs. $136.9 \pm 48.8$ $\mathrm{mg} / \mathrm{dl}, \mathrm{P}=0.402$ ), serum insulin values and HOMA-IR were no different between groups. Figure 1 presents the frequency of each vascular risk factor dichotomized. White subjects more often had high fasting plasma glucose $(83.6 \%$ vs. $76.4 \%, P=$ $0.004)$ and triglycerides $(47.8 \%$ vs. $31.0 \%, P<0.001)$ when compared to black subjects. All other characteristics were similar between groups $(P>0.05)$.

No differences were found regarding medication used (statins: 18.5 vs. $19.3 \%, P=1.000$; fibrates: 1.5 vs. $0.7 \%$, $\mathrm{P}=0.680$; angiotensin converting enzyme inhibitors: $39.5 \mathrm{vs}$. $43.8 \%, P=0.375$ and acetylsalicylic acid: 29.9 vs. $27.7 \%$, $\mathrm{P}=0.673$ ) as well as the number of anti-hypertensive drugs used. 
Table 1 - Clinical and laboratory characteristics of patients with type 2 diabetes mellitus according to ancestry

\begin{tabular}{|c|c|c|c|}
\hline & $\begin{array}{c}\text { Whites } \\
(n=585)\end{array}$ & $\begin{array}{c}\text { Blacks } \\
(\mathrm{n}=195)\end{array}$ & $\mathbf{P}$ \\
\hline Age (years) & $54.0 \pm 8.0$ & $54.8 \pm 10.2$ & 0.354 \\
\hline Male - n (\%) & $204(35.3)$ & $69(34.9)$ & 0.932 \\
\hline Diabetes duration (years) & $9.6 \pm 7.7$ & $8.8 \pm 7.3$ & 0.201 \\
\hline Body Mass Index (kg/m²) & $29.7 \pm 5.5$ & $29.9 \pm 5.0$ & 0.182 \\
\hline Obesity - n (\%) & $391(67.2)$ & $119(61.0)$ & 0.185 \\
\hline Waist circumference $(\mathrm{cm})$ & $97.3 \pm 12.6$ & $98.4 \pm 13.1$ & 0.482 \\
\hline $\begin{array}{l}\text { Women } \\
\text { Men }\end{array}$ & $100.0 \pm 11.2$ & $98.9 \pm 9.6$ & 0.484 \\
\hline Current Smoking habit - $\mathrm{n}(\%)$ & $134(23.0)$ & $44(22.8)$ & 0.942 \\
\hline Hypertension - n (\%) & $368(62.1)$ & $128(67.0)$ & 0.284 \\
\hline Systolic Blood Pressure (mm Hg) & $139.9 \pm 22.7$ & $139.6 \pm 22.1$ & 0.854 \\
\hline Diastolic Blood Pressure (mmHg) & $86.2 \pm 12.5$ & $86.2 \pm 12.9$ & 0.956 \\
\hline Fasting plasma glucose (mg/dl) & $180.7 \pm 74.0$ & $167.5 \pm 80.9$ & 0.070 \\
\hline Alc test $(\%)$ & $7.2 \pm 2.2$ & $7.3 \pm 2.5$ & 0.840 \\
\hline Total cholesterol (mg/dl) & $212.7 \pm 46.5$ & $209.2 \pm 51.7$ & 0.428 \\
\hline HDL cholesterol (mg/dl) & $44.8 \pm 12.1$ & $48.3 \pm 13.5$ & 0.002 \\
\hline LDL cholesterol (mg/dl) & $133.2 \pm 43.8$ & $136.9 \pm 48.8$ & 0.402 \\
\hline Triglycerides (mg/dl) & $152[34-1236]$ & 115 [35-892] & $<0.001$ \\
\hline Urinary Albumin Excretion (mg/l) & $7.10[0.1-1010]$ & $9.05[1-2235]$ & 0.283 \\
\hline HOMA-IR $(n=132)$ & $5.83[0.27-61.9]$ & $5.20[0.61-41.5]$ & 0.786 \\
\hline
\end{tabular}

HOMA-IR = Homeostasis Model Assessment

Data are expressed as means \pm SD or number of cases (\%).
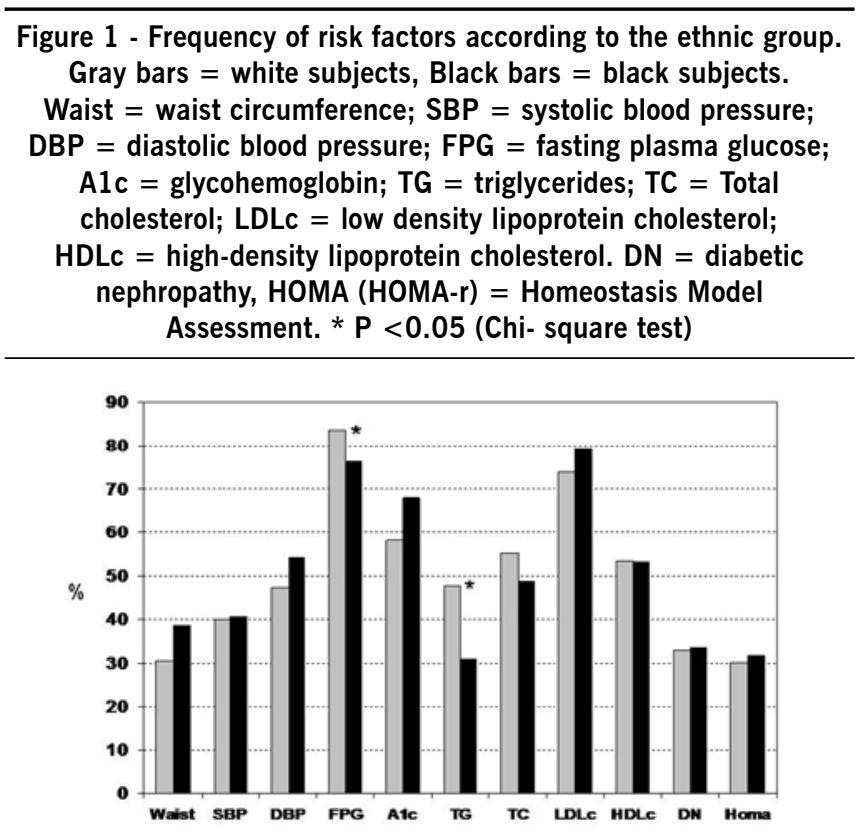

\section{Discussion}

Prevalence of classic micro- and macrovascular risk factors, as well as of markers of insulin resistance in this sample of patients with type 2 DM without advanced renal disease, was similar among black and white individuals.
Traditionally, higher levels of systolic and diastolic BP and more severe hypertension have been described in black individuals compared to whites, both in diabetic ${ }^{14,15}$ and non-diabetic individuals ${ }^{21,22}$. In the present sample, BP levels were similar between groups. This discrepancy in the findings can be attributed to the fact that in previous studies, individuals with kidney disease were not excluded. Since black patients present a higher prevalence of DN, the higher pressure levels reported may result from hypertension secondary to nephropathy, falsely increasing prevalence and severity of hypertension in black individuals. In this study only patients with 1,2 and 3 stages of renal disease ( $>30 \mathrm{ml} / \mathrm{min} / 1,73 \mathrm{~m}^{2}$ ) according to NKF were assessed. Unfortunately, data about the dose of anti-hypertensive medications is not available. We could suppose that a higher dose of such medications among black subjects could obscure a difference. On the other hand, number of classes of medication used was similar between white and black subjects.

We have previously shown that black individuals present a higher prevalence of end-stage renal disease and severe DR ${ }^{12}$. In order to identify possible risk factors for these complications, patients at advanced stages of these complications were not included. The evaluation of a population free of renal disease enables identification of risk factors present in the earliest stage of the disease. As such, the similar prevalence of the main risk factors for DM complications in this sample shows the marked role of ethnicity as a risk factor for micro and macrovascular disease in diabetic patients.

Studies of European and American populations suggest a higher frequency of obesity ${ }^{5} 6$, metabolic syndrome ${ }^{6}$ and worse glycemic control ${ }^{7}$ in the black population, which might explain 
the higher prevalence of chronic complications of DM and worse evolution of DN and DR in this population. Recently, in a meta-analysis performed in American patients with type 2 DM, patients of African ethnicity had worse metabolic control than whites $^{23}$. Black patients presented a mean A1c $0.65 \%$ higher than whites ${ }^{23}$. Data on the Brazilian population are scarce and, in the present sample, the glycemic control was similar among the ethnic groups. With regard to the lipid profile, white patients had higher triglyceride levels and lower HDL values, showing a better cardiovascular profile of patients with African ancestors. These findings agree with studies made with African-Americans who also presented a better lipid profile than whites ${ }^{1,15}$.

A possible limitation of this study was the method used for the ethnic classification of individuals. Definition of ethnicity followed that advocated by IBGE, which classifies individuals as black, white and mixed, by self-definition. The evaluation of ethnic ancestry should ideally be performed using molecular markers. In a study evaluating molecular markers of African ancestry in individuals from several regions of Brazil, Parra et at. ${ }^{24}$ demonstrated that the analysis of ethnic ancestry according to skin color is not reliable in the Brazilian population in general, especially in the Northeast and Southeast, where there is greater miscegenation. However, in the Southern region of Brazil there was a better correlation between skin color and genetic markers of ancestry ${ }^{24}$. However, this methodology would have a high cost, making its use difficult in studies with a large number of individuals. In order to minimize possible classification errors, we evaluated only black or white individuals.

Socioeconomic status and level of access to medical services were described in previous studies as possible factors responsible for the higher prevalence and greater severity of DM complications in black patients ${ }^{7}$. However, patients evaluated in this study population are part of the same health care system with the same access to diagnostic methods and medication.

\section{Conclusion}

In this sample of patients from Southern Brazil with type 2 DM and preserved renal function, there were no differences among the ethnic groups concerning classic metabolic and clinical risk factors. The study of non-conventional risk factors and genetic aspects is essential to better understand the determinants of the worst outcomes presented by the African-Brazilian population and enable the planning of preventive measures and/or intensification of DM treatment in black patients.

\section{Conflict of interest: none}

\section{Resumo}

COMPARAÇÃo de FATORES DE RISCO PARA COMPLICAÇõES MICRO E MACROVASCULARES EM PACIENTES COM DIABETES MELLITUS TIPO 2 NEGROS E BRANCOS

ObJetivo. A prevalência das complicações crônicas do Diabetes mellitus (DM) é maior nos negros. A razão para esse achado é desconhecida. O objetivo desse estudo é analisar os fatores de risco para doença micro e macrovascular em pacientes com DM tipo 2 de acordo com a etnia.

Métodos. Foi realizado estudo transversal avaliando 780 pacientes. Todos pacientes realizaram avaliação clinico/ laboratorial. A etnia foi autoreferida em branca $(n=585)$ ou negra $(n=195)$.

RESUltados. Os pacientes negros apresentaram níveis menores de triglicerídeos $[115$ (35-892) vs. 152 (34-1236) $\mathrm{mg} / \mathrm{dl}$; $P<0.001]$ e maiores de HDL colesterol que os brancos (48.3 \pm 13.5 vs. $44.8 \pm 12.1 \mathrm{mg} / \mathrm{dl} ; P=0.002)$. Não houve diferença entre os grupos quanto à glicemia de jejum, teste A1c, LDL e colesterol total, níveis pressóricos, insulina e Homa-ir. Não houve diferença no uso de medicações (estatinas: 18.5 vs. $19.3 \%, P=1.000$; fibratos: 1.5 vs. $0.7 \%, P$ $=0.680$; inibidores da enzima conversora da angiotensina: 39.5 vs. $43.8 \%, P=0.375$; acido acetilsaliscílico: 29.9 vs. $27.7 \%, P=0.673)$.

Conclusão. Não houve diferença na prevalência dos fatores de risco convencionais para doença micro e macrovascular entre os grupos étnicos. O estudo de fatores não-convencionais e genéticos é essencial para a elucidação dos determinantes dos piores desfechos apresentados pela população diabética afrobrasileira. [Rev Assoc Med Bras 2009; 55(3): 308-12]

Unitermos: Diabetes mellitus. Etnia. Complicações crônicas. Fatores de risco.

\section{REFERENCES}

1. Organization WHO. WHO Study Group. Diabetes Mellitus. Geneve: WHO; 1985. p.727. [Technical Report Series]

2. Ethnicity and cardiovascular disease. The incidence of myocardial infarction in white, South Asian, and Afro-Caribbean patients with type 2 diabetes (U.K. Prospective Diabetes Study 32). Diabetes Care. 1998;21:1271-7.

3. Karter AJ, Ferrara A, Liu JY, Moffet HH, Ackerson LM, Selby JV. Ethnic disparities in diabetic complications in an insured population. JAMA. 2002;287:2519-27.

4. Young BA, Maynard C, Boyko EJ. Racial differences in diabetic nephropathy, cardiovascular disease, and mortality in a national population of veterans. Diabetes Care. 2003;26:2392-9.

5. McClellan WM. Epidemiology and risk factors for chronic kidney disease. Med Clin North Am. 2005;89:419-45.

6. Krop JS, Coresh J, Chambless LE, Shahar E, Watson RL, Szklo M, et al.. A community-based study of explanatory factors for the excess risk for early renal function decline in blacks vs whites with diabetes: the Atherosclerosis Risk in Communities study. Arch Intern Med. 1999;159:1777-83.

7. Perneger TV, Whelton PK, Klag MJ. Race and end-stage renal disease. Socioeconomic status and access to health care as mediating factors. Arch Intern Med. 1995;155:1201-8.

8. Powers DR, Wallin JD. End-stage renal disease in specific ethnic and racial groups: risk factors and benefits of antihypertensive therapy. Arch Intern Med. 1998; 158:793-800.

9. US Renal Data System. USRDS Annual Data Report Md: National Institute of Diabetes and Digestive and Kidney Diseases. Washigton: National Institutes of Health; 1995.

10. Brancati FL, Whittle JC, Whelton PK, Seidler AJ, Klag MJ. The excess incidence of diabetic end-stage renal disease among blacks. A population-based study of potential explanatory factors. JAMA. 1992;268:3079-84.

11. Vaccaro O, Stamler J, Neaton JD. Sixteen-year coronary mortality in black and white men with diabetes screened for the Multiple Risk Factor Intervention Trial (MRFIT). Int J Epidemiol. 1998;27:636-41.

12. Gerchman F, Burttet L, Nabinger G, Picon P, Zanatta C, Lisboa H, et al. High prevalence of macrovascular and microvascular disease among black patients with type 2 diabetes mellitus. Diabetes. 2005;(Suppl 1):A548.

13. Gross JL, Azevedo MJ, Silveiro SP, Canani LH, Caramori ML, Zelmanovitz T. Diabetic nephropathy: diagnosis, prevention, and treatment. Diabetes Care. 2005; 28:164-76.

14. Park YW, Zhu S, Palaniappan L, Heshka S, Carnethon MR, Heymsfield SB. The metabolic syndrome: prevalence and associated risk factor findings in the US population from the Third National Health and Nutrition Examination Survey, 1988-1994. Arch Intern Med. 2003;163:427-36.

15. Davis TM, Cull CA, Holman RR. Relationship between ethnicity and glycemic control, lipid profiles, and blood pressure during the first 9 years of type 2 diabetes: U.K. Prospective Diabetes Study (UKPDS 55). Diabetes Care. 2001;24:1167-74. 
16. Lteif AA, Han K, Mather KJ. Obesity, insulin resistance, and the metabolic syndrome: determinants of endothelial dysfunction in whites and blacks. Circulation. 2005;112:32-8.

17. IBGE. Instituto Brasileiro de Geografia e Estatística; 2006. [citado set 2006]. Disponível em: http:// www.ibge.gov.br.

18. Zelmanovitz T, Gross JL, Oliveira JR, Paggi A, Tatsch M, Azevedo MJ. The receiver operating characteristics curve in the evaluation of a random urine specimen as a screening test for diabetic nephropathy. Diabetes Care. 1997;20:516-9.

19. Matthews DR, Hosker JP, Rudenski AS, Naylor BA, Treacher DF, Turner RC. Homeostasis model assessment: insulin resistance and beta-cell function from fasting plasma glucose and insulin concentrations in man. Diabetologia. 1985; 28:412-9.

20. Levey AS, Coresh J, Balk E, Kausz AT, Levin A, Steffes MW, et al.. National Kidney Foundation practice guidelines for chronic kidney disease: evaluation, classification, and stratification. Ann Intern Med. 2003;139:137-47.

21. Rosner B, Prineas R, Daniels SR, Loggie J. Blood pressure differences between blacks and whites in relation to body size among US children and adolescents. Am J Epidemiol. 2000;151:1007-9.
22. Cushman WC, Reda DJ, Perry HM, Williams D, Abdellatif M, Materson BJ. Regional and racial differences in response to antihypertensive medication use in a randomized controlled trial of men with hypertension in the United States. Department of Veterans Affairs Cooperative Study Group on Antihypertensive Agents. Arch Intern Med. 2000;160:825-31.

23. Kirk JK, DAgostino RB Jr, Bell RA, Passmore LV, Bonds DE, Karter AJ, et al. Disparities in HbAlc Levels Between African-American and NonHispanic White Adults With Diabetes: A meta-analysis. Diabetes Care. 2006; 29:2130-6.

24. Parra FC, Amado RC, Lambertucci JR, Rocha J, Antunes CM, Pena SD. Color and genomic ancestry in Brazilians. Proc Natl Acad Sci USA. 2003; 100:177-82.

Artigo recebido: 06/02/08

Aceito para publicação: 21/10/08 